\title{
Influence of Product Plot Connection of Product Placement on Purchase Intention
}

\author{
Lin YANG \\ School of Business \\ Northeast Normal University \\ Changchun, China \\ 851945033@qq.com
}

\author{
Cheng-Yue YIN \\ School of Business \\ Northeast Normal University \\ Changchun, China \\ yincy653@nenu.edu.cn
}

\begin{abstract}
In this paper, the purpose of this study is to determine the impact of product plot connection on purchase intention. Through questionnaire method, we found out that product plot connection has significant positive correlation with purchase intention. Brand attitude plays a mediating role in the positive influence of product plot connection on purchase intention. Thus, compared with the product placement with low product plot connection, the product placement with high product plot connection can make consumers show better brand attitude and higher purchase intention.
\end{abstract}

Keywords-Product placement; Product plot connection; Brand attitude; Purchase intention

\section{INTRODUCTION}

Since the 21st century, human beings have really entered the digital age, with the rapid development of modern science and technology. Commercial propaganda overspreads so that traditional advertising market more and more tend to be saturated. Thus, consumers become gradually insensitive to indirect or direct hard advertisement in TV programs. The contradiction between profit pursuit of advertisements and program artistry \& appreciation becomes more and more prominent, which also leads to audiences' evasion of advertisements. Thus, traditional advertisements (i.e. the advertisements played before TV program or video) gain lower and lower attention. The effectiveness of such hard advertisements reduces gradually.

In the age with excessive marketing, audiences can easily filter almost all traditional advertisements. Consumers have generated immunity to traditional marketing mode. Then, product placement emerges

This paper explores the influence of plot connection of product placement on consumers' brand attitude and purchase intention through questionnaire survey.

\section{THEORETICAL BASIS AND RESEARCH HYPOTHESIS}

\section{A. Theoretical basis}

1) Product plot connection of product placement

In With the purpose of promotion, product placement places product, brand name or enterprise name in the film or TV program (D'Astous et al., 2000). Enterprises want to market products or brands through placement and own distinct business appeal. But such appeal is implicit. Such nature makes product placement different from traditional advertisement. Product plot connection of product placement is a characteristic of product placement embodied in the film and TV works. During describing product placement, Russell (1998) applied a 3D framework. The third dimension is product plot connection of product placement. Tiwsakul (2005) judged product plot connection according to the connection with the protagonists in the film and TV works.

Scholars have studied the relationship between product plot connection of product placement and other variables. The research of Russell (2002) shows that, when plot connection is combined with auditory placement, persuasion effect will be stronger. However, when plot connection is combined with visual placement, brand memory will rise, and persuasion effect will decline. Such meaningful story contribution also makes memory become easy. Although product plot connection of product placement has different influence on brand memory for different media, the influence on brand attitude is not limited by media. The research of Homer (2009) indicates that, only when audiences are disturbed by the products or brand information placed obviously and mechanically will they generate resistance, thus leading to negative influence on brand attitude. 


\section{2) Brand attitude}

In the opinion of Keller (1993), brand attitude is the basis of consumers' follow-up purchasing behavior. Brand attitude varies from person to person. For the same product and brand, different consumers may have different brand attitudes. Brand attitude is integral. It is believed that, behavior is the outcome variable of attitude. The researches of Homer and Yoon (1992) show that, two factors of brand attitude (i.e. brand trust and brand emotion) have direct influence on purchase intention. Consumers learn knowledge from the past experience. When they contact the information with persuasion intention again, they can recognize the marketers who try to persuade them with their experience and resist the persuasion behavior. Kim and Littrell (1999) adopted famous Fishbein model to measure tourists' attitude. This mode is generally accepted by numerous scholars. The research proves that tourists' attitude to the culture of the sightseeing place will influence their purchase intention for souvenirs.

\section{3) Purchase intention}

Purchase intention means the willingness of a consumer to purchase the product according at the market price when his monetary income is certain. Purchase intention is the probability of consumer's purchase behavior. The research of Mullet (1985) shows that, purchase intention may be regarded as consumer's subjective tendency to selection of the specific product, and it can serve as an important index to predict consuming behavior. Odds (1991) thought, purchase intention is positively correlated to perceived value, while perceived value is influenced by perceived profit and perceived monetary sacrifice. The study of Zeithaml (2008) indicates that, consumer's value perception will rise with the increase of perceived profit, while high perceived value will promote purchase intention. With the help of the principles of rational behavior model, Li Dongjin (2009) studied the factors influencing purchase intention of Chinese consumers through the influence of Chinese culture on consumers. In his view, under the background of Chinese culture, rational behavioral model should be modified.

\section{B. Research hypothesis}

1) Product plot connection of product placement and brand attitude

Audiences will treat the fragment from commercial perspective. As a result, the fragment loses authenticity. The advertisement with obvious persuasion aim will also disturb audiences' appreciation progress, and it is considered to be crude and bothersome. Even, audiences will be nettled and become dissatisfied, thus leading to the decline of brand attitude. The placement with high product plot connection will not trigger negative brand attitude, because it will not disturb audiences' appreciation progress. In one word, the following hypotheses are proposed:

H1a: Product plot connection has positive effect on brand trust.

H1b: Product plot connection has positive effect on brand emotion.

\section{2) Brand attitude and purchase intention}

In accordance with the model of rational behavior theory, brand attitude has direct influence on purchase intention. It is believed that two factors of brand attitude have positive effect on consumer's purchase intention. Hence, the following hypotheses are proposed:

H2a: Brand trust has positive effect on consumer's purchase intention.

$\mathrm{H} 2 \mathrm{~b}$ : Brand emotion has positive effect on consumer's purchase intention.

3) Product plot connection of product placement and purchase intention

According to the hypotheses about the relationship between product plot connection and brand attitude as well as the hypotheses about the relationship between brand attitude and purchase intention, the following hypotheses are proposed:

H3: Product plot connection of product placement has positive effect on consumer's purchase intention.

\section{DEFINITION AND MEASUREMENT OF VARIABLES}

Based on the definition of D'Astous and Chattier (2000) on product plot connection, the product placement with high product plot connection is related to the scene and the situation of the work, and can be completely integrated in the work. 3 questions provided by Russell (2002) were used to measure product plot connection. Variables of brand attitude and measurable design developed by Paul (2011) were applied. This paper refers to Dong Yu (2011) to define purchase intention and refers to Paul (2011) to measure purchase intention.

\section{EMPIRICAL ANALYSIS}

\section{A. Descroption of survey sample and analysis of reliability and validity}

288 questionnaires were collected. After the ineffective questionnaires were eliminated, there were 263 questionnaires. The men-women proportion was about 5:8, and the age was between 18 and 24 . The education background was basically undergraduate degree or above. According to the statistical results, Cronbach's $\alpha$ values of product plot connection, brand trust, brand emotion and purchase intention are $0.766,0.863$, 0.859 and 0.908 respectively, greater than 0.7 . This result conforms to the requirement of measurement reliability. The factor analysis result of product plot connection shows that, KMO value is 0.717 , greater than 0.7. Bartlett's test significance probability is $0.000<0.001$, and the spherical assumption is rejected. The accumulative variance contribution rate of the scale factor is $68.388 \%$, higher than $60 \%$. The validity conforms to the research requirement. The factor analysis result of brand attitude shows, KMO value is 0.906 , greater than 0.7 . Bartlett's test significance probability is $0.000<0.001$, and the spherical assumption is rejected. 2 factors were extracted form the scale. The accumulative variance contribution rate of the factors is $75.520 \%$, and the validity conforms to the research requirement. The factor analysis result of purchase intention shows that, KMO value is 0.879 greater 
than 0.7. Bartlett's test significance probability is $0.000<0.001$, and the spherical assumption is rejected. The accumulative variance contribution rate of the factors is $73.212 \%$ and the validity conforms to the research requirement.

\section{B. Hypothesis testing}

1) Product plot connection and brand attitude

According to the following table, the determination coefficient $\mathrm{R}$ square is $17.2 \%$ and $17.4 \%$ respectively. The significance probability is less than 0.05 . It thus can be seen that, product plot connection of product placement will generate positive and significant influence on consumer's brand recognition and emotional attitude. $\mathrm{H} 1 \mathrm{a}$ and $\mathrm{H} 1 \mathrm{~b}$ are verified.

TABLE I. REGRESSION ANALYSIS OF PRODUCT PLOT CONNECTION AND BRAND ATTITUDE

\begin{tabular}{|c|c|c|c|c|c|c|}
\hline Model & $\begin{array}{c}\text { Correlation } \\
\text { coefficient } \mathrm{R}\end{array}$ & $\begin{array}{c}\text { Determination } \\
\text { coefficient of } \mathrm{R} \\
\text { square }\end{array}$ & $\begin{array}{c}\text { Adjusted judgment } \\
\text { coefficient } \mathrm{R} \\
\text { square }\end{array}$ & $\begin{array}{c}\text { Estimated standard } \\
\text { error }\end{array}$ & $\begin{array}{c}\text { Fignificance } \\
\text { probability }\end{array}$ \\
\hline Brand trust & $0.415 \mathrm{a}$ & 0.172 & 0.169 & 0.64945 & 54.156 & 0.000 (a) \\
\hline Brand emotion & $0.417 \mathrm{~b}$ & 0.174 & 0.171 & 0.69798 & 55.012 & 0.000 (b) \\
\hline
\end{tabular}

TABLE II. REGRESSION ANALYSIS OF PRODUCT PLOT CONNECTION AND BRAND EMOTION

\begin{tabular}{|c|c|c|c|c|c|}
\hline \multirow[t]{2}{*}{ Model } & \multicolumn{2}{|c|}{ Non-standardized coefficient } & \multirow{2}{*}{$\begin{array}{l}\text { Standardized } \\
\text { coefficient }\end{array}$} & \multirow[b]{2}{*}{$\mathrm{t}$} & \multirow[b]{2}{*}{ Sig. } \\
\hline & B & Standard error & & & \\
\hline (Constant) & \multirow{2}{*}{$\begin{array}{l}2.533 \\
0.338\end{array}$} & \multirow{2}{*}{$\begin{array}{l}0.136 \\
0.046\end{array}$} & \multirow[b]{2}{*}{0.417} & \multirow{2}{*}{$\begin{array}{c}18.596 \\
7.417\end{array}$} & \multirow{2}{*}{$\begin{array}{l}0.000 \\
0.000\end{array}$} \\
\hline Connection & & & & & \\
\hline
\end{tabular}

a. Dependent variable: brand emotion

TABLE III. REGRESSION ANALYSIS OF PRODUCT PLOT CONNECTION AND BRAND TRUST

\begin{tabular}{|c|c|c|c|c|c|}
\hline \multirow{2}{*}{ Model } & \multicolumn{2}{|c|}{ Non-standardized coefficient } & Standardized coefficient & t & \\
\cline { 2 - 3 } & B & Standard error & & 20.046 & 0.000 \\
Constant & 2.541 & 0.127 & 0.415 & 7.359 & 0.000 \\
\hline Connection & 0.312 & 0.042 & & \\
\hline
\end{tabular}

2) Product plot connection and purchase intention

According to the following table, the determination coefficient $\mathrm{R}$ square is $21.2 \%$. The significance probability is less than 0.05 . The model regression effect is significant. When the connection between the product of product placement and the plot is higher, consumer's purchase intention is stronger. $\mathrm{H} 3$ is verified.

TABLE IV. REGRESSION ANALYSIS OF PRODUCT PLOT CONNECTION AND PURCHASE INTENTION

\begin{tabular}{|c|c|c|c|c|c|}
\hline \multirow{2}{*}{ Model } & \multicolumn{2}{|c|}{ Non-standardized coefficient } & \multirow{2}{*}{$\begin{array}{c}\text { Standardized } \\
\text { coefficient }\end{array}$} & Sig. \\
\cline { 2 - 5 } & B & Standard error & & 19.546 \\
(Constant) & 2.517 & 0.129 & 0.460 & 8.378 \\
\hline
\end{tabular}


TABLE V. REGRESSION ANALYSIS OF PRODUCT PLOT CONNECTION AND PURCHASE INTENTION

\begin{tabular}{|l|c|c|c|c|c|c|}
\hline Model & $\begin{array}{c}\text { Correlation } \\
\text { coefficient R }\end{array}$ & $\begin{array}{c}\text { Determinati } \\
\text { on } \\
\text { coefficient } \\
\text { of R square }\end{array}$ & $\begin{array}{c}\text { Adjusted } \\
\text { judgment } \\
\text { coefficient R } \\
\text { square }\end{array}$ & $\begin{array}{c}\text { Estimated } \\
\text { standard } \\
\text { error }\end{array}$ & F & Significance probability \\
\hline & $0.450 \mathrm{a}$ & 0.212 & 0.209 & 0.65984 & 70.187 & 0.000 (a) \\
\hline
\end{tabular}

TABLE VI. REGRESSION ANALYSIS OF PRODUCT PLOT CONNECTION, BRAND ATTITUDE AND PURCHASE INTENTION

\begin{tabular}{|c|c|c|c|c|c|c|}
\hline Model & $\begin{array}{c}\text { Correlation } \\
\text { coefficient R }\end{array}$ & $\begin{array}{c}\text { Determination } \\
\text { coefficient of R } \\
\text { square }\end{array}$ & $\begin{array}{c}\text { Adjusted judgment } \\
\text { coefficient R square }\end{array}$ & $\begin{array}{c}\text { Estimated standard } \\
\text { error }\end{array}$ & $\begin{array}{c}\text { F } \\
\text { probability }\end{array}$ \\
\hline & $0.865 \mathrm{a}$ & 0.749 & 0.746 & 0.37391 & 257.466 & 0.000 (a) \\
\hline
\end{tabular}

3) Product plot connection, brand attitude and purchase intention

According to the following table, the determination coefficient $\mathrm{R}$ square is $74.9 \%$. The significance probability is less than 0.05 . The model regression effect is significant.
Product plot connection and brand attitude will have significant positive influence on purchase intention. We can thus know, when consumers more trust the brand, they will have stronger intention to purchase the product. $\mathrm{H} 2 \mathrm{a}$ and $\mathrm{H} 2 \mathrm{~b}$ are verified.

Table 6. Regression analysis of product plot connection, brand attitude and purchase intention

TABLE VII. REGRESSION ANALYSIS OF PRODUCT PLOT CONNECTION, BRAND ATTITUDE AND PURCHASE INTENTION (2)

\begin{tabular}{|c|c|c|c|c|c|}
\hline \multirow[t]{2}{*}{ Model } & \multicolumn{2}{|c|}{ Non-standardized coefficient } & \multirow{2}{*}{$\begin{array}{l}\text { Standardized } \\
\text { coefficient }\end{array}$} & \multirow{2}{*}{$\mathrm{t}$} & \multirow{2}{*}{ Sig. } \\
\hline & B & Standard error & & & \\
\hline (Constant) & 0.368 & 0.118 & & 3.108 & 0.002 \\
\hline Connection & 0.083 & 0.027 & 0.105 & 3.045 & 0.003 \\
\hline Brand trust & 0.314 & 0.056 & 0.301 & 5.650 & 0.000 \\
\hline Brand emotion & 0.533 & 0.052 & 0.551 & 10.320 & 0.000 \\
\hline
\end{tabular}

\section{CONCLUSION}

Through the research, we realize that, product plot connection of product placement will influence purchase intention through the influence on brand attitude. Thus, advertisers and entrepreneurs must cautiously consider product plot connection of product placement, and choose the film and TV works with certain connection with the brand to make the advertisement natural and effective. The information with high product plot connection is hidden in the content and can act on consumer's purchase intention for a longer time. In this research, the respondents are mostly college students who are not strange to the concept and mode of product placement. Besides, they actively coordinated with the survey, and could easily enter the question answering scene. But, in social life, the audiences of product placement cover each class. Different social classes have different perception. Student samples could be easily gained by the author, but they only occupy a small proportion in the consumption environment. Thus, it is very hard to explain the whole state of consumers. So the author hopes scholars can choose the objects with different age and background for the study in the future, apply different media and select different brands to avoid the impact of TV play preference on the advertising effect. Meanwhile, scholars should screen samples, choose the samples who do not watch the film for study, control the influence of samples' preference to the actors and story on the result and make the results comply with realistic conditions as far as possible.

\section{ACKNOWLEDGMENT}

This study was supported by the National Social Science Foundation of China (No. 15BGL092). 


\section{REFERENCES}

[1] D'Astous, A., \& Chartier, F. (2000). A study of factors affecting consumer evaluations and memory of product placements in movies. Journal of Current Issues \& Research in Advertising, 22(2), 31-40.

[2] Dodds, W. B., Monroe, K. B., \& Grewal, D. (1991). Effects of price, brand, and store information on buyers' product evaluations. Journal of Marketing Research, 28(3), 307-319.

[3] Homer P M. (2009) Produce placements: The impact of placement type and repetition on attitude. Journal of Advertising, 38(3), 21-31.

[4] Keller, K. L. (1993). Conceptualizing, measuring, and managing customer-based brand equity. Journal of Marketing, 57(1), 1-22.

[5] Soyoung, K., \& Littrell, M. A. (1999). Predicting souvenir purchase intentions. Journal of Travel Research, 38(2), 153-162.

[6] Mullet, G. M., \& Karson, M. J. (1985). Analysis of purchase intent scales weighted by probability of actual purchase. Journal of Marketing Research, 22(1), 93-96.

[7] Russell, C. A. (2002). Investigating the effectiveness of product placements in television shows: the role of modality and plot connection congruence on brand memory and attitude. Journal of Consumer Research, 29(3), 306-318.

[8] Wu, P. C. S., \& Wang, Y. (2011). The influences of electronic word - of - mouth message appeal and message source credibility on brand attitude. Asia Pacific Journal of Marketing \& Logistics, 23(4), 448-472.

[9] Russell, C. A. (1998).Toward a Framework of Product Placement: Theoretical propositions. Advances in Consumer Research, 25(1), 357362.

[10] Tiwsakul, R., Hackley, C., \& Szmigin, I. (2005). Explicit, non-integrated product placement in british television programmes. International Journal of Advertising, 24(1), 95-111.

[11] Zeithaml, \& ValarieA. (2008). Services marketing: integrating customer focus across the firm /-4th ed. China Machine Press.

[12] Li Dongjin, Wu Bo, Wu Ruijuan (2009), Model of Chinese Consumer's Purchase Intention - Modification of Fishbein Rational Behavior Model. Management World (1), 121-129. 